\section{View from the north}

\section{Walter Gratzer}

The Atheist and the Holy City: Encounters and Reflections. By George Klein. MIT Press: 1990. Pp. 200. £14.95, \$17.95.

THE riposte to a journalist's inquiry about life on Mars - that the Martians are already among us: they are called Hungarians - has been variously attributed to Arthur Koestler and Leo Szilard. Certainly the generation that grew up in Hungary at about the time of the First World War and the years following, succeeded in infiltrating much of European and American science. George Klein, who took root in Sweden, is of their number. He came to know Leo Szilard, physicist, biologist and political activist, as a friend and his vignettes of Szilard's life and character were for me the most rewarding parts of his collection of reviews and essays.

Szilard may have been something of a dilettante - one

who in the course of one revolving moon was statesman, fiddler, chemist and buffoon

- but it was he who first perceived the possibility of a nuclear chain reaction and at whose urging Einstein sent the celebrated letter to Roosevelt, that can be said to have launched the Manhattan project. Szilard was an inexhaustibly gregarious man and a tireless quidnunc: a law of physics had it that wherever two physicists met Szilard was created. He was moreover irrepressibly disputatious. The story (doubtless apocryphal) went that a jury on which he served in Chicago could reach no verdict, for Szilard was absolute for the accused man's guilt, the other jurors for his innocence. The judge invited the jury to retire and try again; they failed once more to agree, but this time Szilard found for innocence and the other eleven for guilt.

When Szilard became interested in biology his method of informing himself was to pay unannounced visits to biologists around the world and interrogate them minutely on their work, scribbling the while in his notebook. He would conclude the interview by holding out his pen with the peremptory demand, "sign please". And on then to the next laboratory on his circuit, like, as François Jacob put in his memoirs, "a sort of fat bumblebee, spreading pollen".

Klein too was subjected to these epiphanies, when Szilard would materialize at the door of his office and resume the conversation where he had left it the year before. Thereby too hangs a less familiar tale, for on one such occasion Klein followed his friend into the lavatory and noticed blood in the urinal. Szilard admitted when taxed that he had been passing blood for six months; he was too busy, he said, to trouble himself about it. Klein took him to a urologist, who diagnosed a massive bladder tumour. Szilard mistrusted doctors; he rejected an operation, then accepted, changed his mind, offended the urologist and eventually opted, against advice, for radiation treatment at unprecedently high doses, and angles of irradiation that he himself determined. The cancer melted away and Szilard died in his sleep eight years later of a stroke.

Death recurs in these pages and indeed the book got started, it seems, in consequence of a commendation that Klein, as an expert on cancer, was asked to write for In the Face of Death, a reflection by a Swiss lawyer, Peter Noll, on his own impending demise. Noll had bladder cancer and his life could have been preserved by an operation, but he chose to let the disease take its course. Klein is deeply impressed by Noll's quietist approach to death - so different from Szilard's and from that of fighters, such as Peter Medawar, who gave so vibrant an account of why he preferred to stay alive. Klein suggests that these contrasted attitudes are represented in their extreme forms by the Japanese - who, he says, will not discuss mortality even between doctor and patient - and the Chinese, who look on the grim reaper's visage with the composure that Noll emulated and the Japanese envy. Klein asked an eminent and ageing Japanese oncologist to explain this yearning. After a long silence came the answer:
"Water birds fly over a lake. The lake surface, my soul. The birds' shadows the events."

Klein occupies a distinguished position in cancer research and appears to spend much time travelling: his experience of scientific affairs clearly goes well beyond the laboratory. The presence of a foreword by Lewis Thomas sets the seal indeed on his standing in the international scientific ascendency. Thomas extols his academic lustre, and reveals - just to put the rest of us in our place presumably that he is the author of 800 papers. Well, no matter. Klein has put his advantages to good account in these pieces. He is a sagacious observer of science and its practitioners; I enjoyed his essay on the social milieus that make for acceptance or rejection of new ideas. There are several good stories, such as the ancedote about Pasteur in old age: his young colleagues, observing the patron's habit of pausing from his work to mutter something to himself, wondered what the incantation could be that appeared to sustain him. One of his students drew close unobserved and this is what he heard: "il faut travailler". (Better by far than the story that clung to a famous Commodore of the Cunard line, who at moments of crisis would also soliloquise under his breath; the cabin-boy, deputed to eavesdrop heard: "port is left, starboard is right".)

Klein's dissertation on viruses and oncogenes is both enlightening and readable and his ruminations on the nature of evil and other riddles of the human condition are wholly sympathetic. Among the belle-lettristes of science he is not quite in the class of Jacob and Perutz, but his is a likable book with quite a number of buried truffles.

Walter Gratzer is in the MRC Cell Biophysics Unit, Drury Lane, London WC2B 5RL, UK.

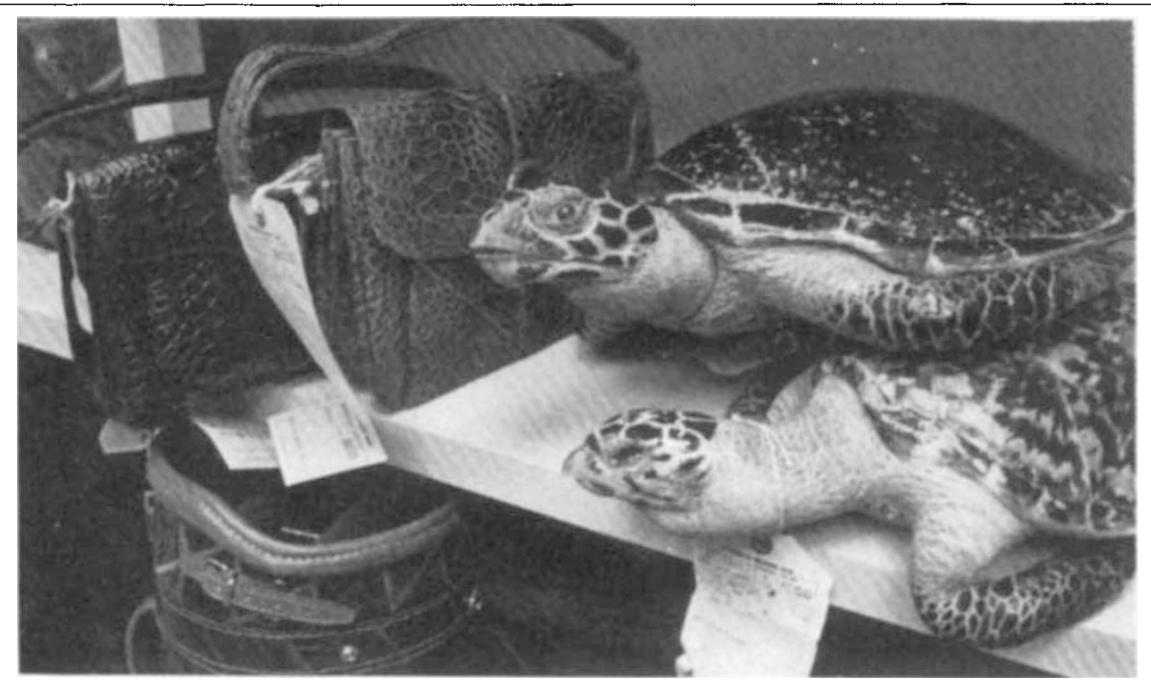

Sea turtle products - bags, a golf holdall and two stuffed hawksbills. Trade such as this, legal in many nations, accounts for thousands of deaths. Fight For Surviva/ by R. L. DiSilvestro is published by Wiley, and focuses on the battle to preserve endangered species such as wolves, sharks, dolphins and others. Price $£ 24.95, \$ 32.95$. 